Utah State University

DigitalCommons@USU

$\mathrm{Ca}$

Bee Lab

$5-1-1900$

\title{
LIV.-Observations on Bees Collected at Las Vegas, New Mexico, and in the Adjacent Mountains
}

T. D. A. Cockerell

New Mexico Agricultural College

Follow this and additional works at: https://digitalcommons.usu.edu/bee_lab_ca

Part of the Entomology Commons

\section{Recommended Citation}

Cockerell, T. D. A., "LIV.-Observations on Bees Collected at Las Vegas, New Mexico, and in the Adjacent Mountains" (1900). Ca. Paper 284.

https://digitalcommons.usu.edu/bee_lab_ca/284

This Article is brought to you for free and open access by the Bee Lab at DigitalCommons@USU. It has been accepted for inclusion in $\mathrm{Ca}$ by an authorized administrator of DigitalCommons@USU. For more information, please contact digitalcommons@usu.edu.

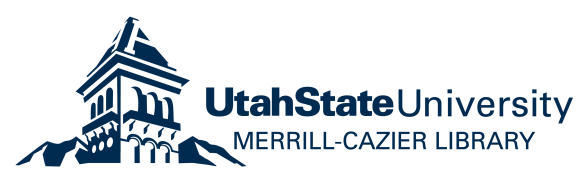




\title{
THE ANNALS
}

\section{AND \\ MAGAZINE OF NATURAL HISTORY.}

\author{
[SEVENTH SERIES.]
}

No. 29. MAY 1900.

LIV.-Observations on Bees collected at Las Vegas, New Mexico, and in the adjacent Mountains. By T. D. A. Cockerell, Professor of Entomology, New Mexico Agricultural College.

\section{Bombus proximus, Cresson, 1863.}

'This has priority of place over Howardi, Cresson, and must be used for the species. The proximus form is the usual one in New Mexico (Monument Rock \&c.), but Miss W. Porter took a male of B. proximus, var. Howardi (B. Howardi, Cress. 1863), at San Ignacio, Sept. 1, 1899. The var. Howardi has the second and third segments of the abdomen yellow (some black hair at the base of the second), whereas proximus proper has the second segment black as well as the first.

\section{Bombus juxtus, Cresson, 1878.}

This has a very perfect mimic in Volucella facialis, Will., which Miss Wilmatte Porter collected in company with it on flowers of wild plum at Beulah, N. M., May 30, 1899.

\section{Andrena Porterce, sp. n.}

o. -12 millim. long.

Black, with black pubescence. Superficially this looks Ann.\& Mag. N. Hist. Ser. 7. Vol. v. 
exactly like $A$. nigerrima, Casad, but it differs as follows :Wings yellower, stigma paler; clypeus much more produced and much more sparsely punctured; malar space much longer, nearly as long as broad; abdomen practically impunctate, the sparse punctures barely visible, the broad hind margin of the first segment, which in nigerrima is so conspicuously punctured, quite smooth and impunctate. 'The process of the labrum is obtuse and entire.

Differs at once from $A$. nigra, Prov., by the very sparsely punctured clypeus.

Hab. Las Vegas Hot Springs, N. M., at flowers of Salix, spring of 1899 (Wilmatte Porter).

The following four species all appear in the latter half of summer or early autumn, and agree in having the abdomen of the tessellate-impunctate type and the process of labrum produced and emarginate. 'They may be separated as
follows:-

Mesothorax smooth, shining; hair at apex of abdomen white.

Process of labrum with a deep emargination; stigma black ...............

Process of labrum with a shallow emargina-

Mesothorax granular, dull.
Process of labrum usually with ranthigera, Ckll. albovirgata, Ckll. emargination; size larger; hair at apex of abdomen sooty.

Clypeus densely punctured

Process of labrum with punctured .... apucheorum, var. gination; size smaller; clypeus tessellate and rather sparsely punctured .. segregans, Ckll.

\section{Andrena xanthigera, sp. $\mathrm{n}$.}

.- - Length about 9 millim.

Black, with rather long greyish-white pubescence. Eyes parallel, facial quadrangle broader than long; cheeks ample; vertex dull and granular; front striated; antenmæ ample; little ferruginous beneath towards the ends; sides of face with rather abundant long hair; clypeus shining, very closely punctured at the sides, sparsely in the middle, with an punctate median line; malar space almost obsolete; process of labrum produced, deeply emarginate, the emargination rectangular; mesothorax slining but microscopically tessellate, with sparse, feeble, minute punctures, and a few larger ones scattered about; metathorax granular, dull, basal area triangular, without a rim, very feeble, longitudinally plicate at the sides of the extreme base; tegulæ dark testaceous; wings hyaline, faintly but quite noticeably smoky at apex. nervures dark brown, stigma black; third submarginal cell long, narrowed more than half to marginal ; legs black, with pale pubescence; small joints of tarsi clear ferruginous; basal joint of middle tarsus broadened; spurs white; abdomen rather broad, microscopically tessellate, with a sericeous lustre; all the segments with apical bands of long white hair, that on the first very thin, on the others very dense; apical pubescence also white.

Hab. San Ignacio (between Las Vegas and Beulah), N. M., Sept. 1, 1899 (Wilmatte Porter).

$/$ Closely related to $A$. nubecula, Smith, but the cloud at the apex of the wings is not nearly so dark, the first abdominal segment has a hair-band (wanting in nubecula), and the size is a little larger. Perhaps it is only a geographical race of $A$. nubecula, which inhabits Canada and the U. S. east of the plains, coming as far west as Lincoln, Nebraska, whence I have specimens collected in August and September, sent by Prof. L. Bruner. 'The type specimen of $A$. xanthigera has the sides of the metathorax and the hind fernora and tibix heavily loaded with orange pollen, doubtless gathered from one of the Compositæ. A Lincoln nubecula is loaded in exactly the same way.

\section{Andrena albovirgata, sp. $\mathrm{n}$.}

o.- -Length about $7 \frac{1}{2}$ millim.

Similar to $A$. xanthigera, but differing in the basal process of the labrum having only a shallow gently rounded emargination; the stigma light brown; the wings not clouded at apex; the first abdominal segment with the band thinner or reduced to some scattered hairs; the shining disk of mesothorax with weaker excessively minute punctures.

Hab. San Ignacio, N. M., Sept. 1, 1899; two (Wilmatte Porter). They carry a very small amount of orange pollen.

\section{Andrena apacheorum, Ckll., 1897, var. $a$.}

\&.-Length about $9 \frac{1}{2}$ millim.

Black, with dull white pubescence, except at the apex of the abdomen, where it is greyish brown, and on the tibix and tarsi, where it is mostly brownish grey. Facial quadrangle broader than long; vertex dull and granular; front striated; antennæ obscurely brown beneath towards tips; clypeus 
strongly and densely punctured, a small space in the middle near the anterior margin smooth and shining; anterior margin of clypeus transversely sulcate; process of labrum with a deep angular emargination; mesothorax dull, minutely tessellate, with very sparse and feeble punctures; legs black, small joints of tarsi slightly ferruginous, spurs white; base of metathorax dull, granular, not enclosed; tegulæ dark; wings yellowish, nervures brown, stigma deep honey-colour; abdomen broad, microscopically tessellate, first four segments with broad but very thin apical bands of dull white hair.

Hab. Hill above Beulah, N. M., Aug. 19, 1899 (Wilmatte Porter).

I thought at first this might be distinct from apacheorum, but after careful comparison I must regard it as the same, notwithstanding the difference in the process of the labrum, which in the type of apacheorum is truncate, the truncation depressed centrally, but scarcely emarginate.

\section{Andrena apacheornm, var. $\beta$.}

q.-Differs as follows:- Process of labrum with emargination rounded, not angular ; clypeus shining, sparsely punctured on the disk, with a median impunetate stripe; wings
quite dark, stigma somewhat darker.

Hab. Hill above Beulah, Aug. 19 (Wilmatte Porter).

Another form of apacheorum, which appears to be remarkably variable. 'T'his insect resembles $A$. solidaginis and A. asteris in many of its characters, but the abdominal bands of solidaginis are much narrower and asteris differs in various small details.

\section{Andrena segregans, sp. n.}

o.-Length about 8 millim.

Black, with white pubescence, dull on mesothorax and scutellum, with a decided grey tint, some black lairs on vertex and about the base of the antenna; hair of tarsi greyish inclining to fuscous, of apex of abdomen stained with greyish brown, but not actually sooty. Process of labrum broadly truncate, the truncation concave, but only slightly so ; clypeus with strong punctures, not very dense; antennæ dark; vertex granular; mesothorax dull, microscopically tessellate, with sparse feeble punctures; basal area of metathorax triangular, minutely roughened, with a slight and delicate rim, obsolete medially; tegulæ dark; wings smoky; stigma and nervures very dark brown; abdomen shining, practically impunctate, narrower than in apacheorum, with thin white hair-bands on the apical margins of the segments, that on the first almost obsolete.

ऊ.- Similar in most respects; face entirely dark; antennæ entirely dark; abdomen a little more punctured, more gene. rally pruinose, with the hair-bands less distinct; pubescence generally longer, but of the same colour on head and thorax.

Hah. Beulah, N. II., July 26, 1899 (Wilmatte Porter).

\section{Andrena vicina, Smith, 1853.}

Hab. Beulah, N. M., May 30, 1899, at flowers of wild plum, 3 o (Wilmatte Porter).

New to New Mexico.

I

Andrena platyparia, race occidentalis, Ckll., 1896.

Hab. Beulah, N. M., July 26, 1899, 1 o (Wilmatte Porter).

\section{Andrena argemonis, Ckll., 1896.}

Hab. Las Vegas, July 21, at flowers of Petalostemon candidus, 1 or, 1 o (Ckll.); July 30, at flowers of Cleome serrulata, 1 (Wilmatte Porter); Aug. 11, at flowers of Petalustemon candidus, 2 o (W. Porter). Gallinas River, at La Cueva, Aug. 6, 1 \& (Porter \& Ckll.). San Geronimo, at flowers of Petalostemon candidus, July 23, 1 $\delta, 3 \leftarrow$ (A. Garlick).

Andrena americana, Dalla Torre, 1896.

Hab. San Ignacio, Sept. 1,2 (Wilmatte Porter) ; Beulah, end of August, 1 ot (Ckll.).

New to New Mlexico, and quite unexpected here. The specimens agree with those from Connecticut.

\section{Andrena helianthi, Rob., 1891.}

Hab. Las Vegas, Aug. 11, 1 \& (A. Garlick) ; Aug. 2, at flowers of Verbesina encelioides, 1 o (Wilmatte Porter); Aug. 12, at flowers of Helianthus annuus, 1 ô (A. Garlick). Rociada, Aug. 20, 1 \& (Ckll.).

\section{Andrena mellea, Cresson, 1868.}

Hab. Las Vegas, Aug. 11, 1 \& (A. Garlick).

A beautiful species, previously known only by the unique type. 
Andrena aureocincta, Ckll., 1896.

Hab. San Ignacio, Sept. 1, 1 б (Wilmatte Porter). Previously known only by the unique type.

\section{Andrena grandior, Ckll., 1897.}

Hab. Beulah, July 26, 1 q (Wilmatte Porter) ; Aug. 18, 1 o (Ckll.).

Previously known only from Washington State. The specimens are 10 millim. long, thus a trifle smaller than the type. Easily known from rugosa by the broad lateral frontal depressions, which follow the orbital margin, whereas in rugosa they diverge from it below, leaving a smooth shining space adjacent to the eye. A. rugosa is also a vernal species, flying in April.

\section{Andrena nitidior, sp. $\mathrm{n}$}

\section{o.-Length 12 millim.}

Black, with ochraceous pubescence, dense on head and thorax; abdomen shining, microscopically tessellate, the excessively minute sparse punctures indicating the origins of the almost invisible short hairs; the sides rather more hairy, tending to form thin bands at the sides of the apical margins of the second and third segments and all along the margin of the fourth; apex densely clothed with light reddish-ochraceous hair; hind tarsi and small joints of the other tarsi ferruginous; wings smoky, a little darker on outer margin; stigma and nervures dark ferruginous; stigmá very narrow; second submarginal cell large; process of labrum broad and low, emarginate.

Very similar to $A$. helianthi, with the same pubescence on the head and thorax, the same narrow stigma, \&c., but easily distinguished by the smaller shining abdomen and the darker wings. The base of the metathorax is minutely granular, the enclosure only defined by the absence of hair and its fine sculpture; the mesothorax is entirely dull and coarsely granular, the parapsidal grooves distinct; the lateral facial depressions are broad and follow the orbital margin to their lower ends; the clypeus is strongly punctured; the flagellum is only faintly ferruginous beneath towards the end.

Hab. San Ignacio, Sept. 1, 1899, 2 \& (Wilmatte Porter).

One has the hind tibiæ light ferruginous, with a dark blotch in front and behind. In the other the hind tibiæ are covered with bright orange pollen, as also the femora and base of metathorax. Superficially the insect has a considerable resemblance to $A$. pruni, Rob.

\section{Andrena semirufa, sp. n.}

\section{9.-Length almost 13 millim.}

Black, with reddish-ochraceous pubescence, fairly dense on head and thorax, ferruginous on the mesothorax and scutellum ; hair at apex of abdomen black. Facial quadrangle about square; vertex microseopically tessellate; lateral frontal depressions receding from the orbital margin below ; antennæ dark; clypeus strongly, densely, and more or less confluently punctured, with a narrow longitudinal impunctate ridge; process of labrum broad, ending in a thickened truncation, not in the least emarginate; malar space short, but distinct, minutely punctured; mesothorax minutely tessellate, closely punctured at the sides, sparsely in the middle; base of metathorax granular, defined only by an impressed line; tegulæ very dark brown; wings yellowish, nervures dark brown, stigma dark ferruginous; third submaroinal cell narrowed more than half to marginal; scopa of hind femora and tibia very abundant; pubescence of tarsi grey-brown on outer side, reddish within, spurs orange; abdomen microscopically tessellate, shining, with only minute hair-punctures; dorsal surface of abdomen practically nude, the margins of the segments not banded; sides hairy; vertex with thin bands of long pale brownish hairs.

Hab. Las Vegas Hot Springs, at flowers of Salix, spring of 1899 (Wilmatte Porter).

Judging from Smith's short description, this must come very close to $A$. nivalis, Sm., from Hudson's Bar. It also runs to nivalis in Provancher's table of Canadian Andrence; but it is, I think, certainly a different species. In Schmiedeknecht's table of European Andrence ( 9 ) it runs to 64, but does not agree with the species there indicated.

Paranomia Nortoni (Cresson, 1868, as Nomia).

Hab. Las Vegas, July 18, at flowers of Lycium vulgare, 1 ơ (Wilmatte Porter).

\section{Anthophora Porterce, sp. n.}

8.-Length 15 millim.

Very robust ( 6 millim. between the bases of the wings), black, densely clothed on head, thorax, and base of abdomen with erect greyish-white hair, very slightly mixed with black. Clypeus nude, but densely fringed with snow-white hair; clgpeus (except the narrow anterior edge), labrum (except two large spots at sides of base), subtriangular (rose- 
thorn shaped) lateral face-marks, and broad stripe on scape pale primrose-yellow ; mandibles wholly dark, slender, with a distinct tooth within near tip; eyes olive-green; tongue about 12 millim. long; pubescence of thorax so dense as to conceal the surface; tegula piceous; wings hyaline, with a faint brownish tinge; nervures piceous, first recurrent nervure joining second submarginal cell about its middle; legs black, even to the tarsi (claws ferruginous at base), with very long white hair; tarsi with some black hair on inner side ; spurs black ; basal joint of hind tarsus neither broadened nor toothed; middle tarsus with very long black and white hairs, last joint ciliated on each side with long black hairs, something like a peacock's feather; abdomen densely hairy at base, thinly so beyond, so as to appear dusty ; hind margins of the segments brownish; third and following segments with inconspicuous black hairs; apex narrowly truncate.

\%.-Similar; face wholly black, clypeus more strongly punctured; wings browner; hair of vertex and mesothorax distinctly mixed with black; pygidial plate long and very narrow.

Hab. Romeroville, N. M., April 29, 1899, at flowers of wild gooseberry, 1 o (Wilmatte Porter) ; Mojave Desert, California, 1 o (Ehrhorn).

Looks like a species of Centris.

Anthophora occidentalis, Crẹsson, 1869.

Hab. Las Vegas, July 20, at flowers of Cnicus ochrocentrus, 1 (Ckll.) ; July 20, at flowers of Cleome serrulata, 1 (Wilmatte Porter); July 22, at flowers of Convolvulus sepium (var.), 1 ऊ (Wilmatte Porter).

Anthophora bomboides, Kirby, var. neomexicana, nov.

б $9 .-$ Pubescence of vertex, thorax, and abdomen except apex bright orange-ferruginous, of cheeks black in female, white in male; in the female the red hair covers the first three abdominal segments (the others being black), in the male it covers the first three and most of the fourth. Clypeus and face-marks of male cream-colour; apex of abdomen bidentate.

Hab. Las Vegas, June 18, at flowers of alfalfa, $1 \sigma^{*}$ (Ckil.) ; July 8, at flowers of Lycium vulgare, 2 \& (Wilmatte Porter) Beulah, May 30, 1 \& (Wilmatte Porter). Las Vegas, June 3, 1 \& (R. Devine).
In typical bomboides the pubescence, where not black, is white or whitish, and on the male abdomen it covers the three first dorsal segments. This is from $65^{\circ} \mathrm{N}$. lat.

In var. canadensis, Cresson ( $\sigma^{*}$, the pubescence is lemonyellow instead of white, and only the first and base of second dorsal segments of the abdomen are clothed with yellow hair. This is from Ontario. A male from Olympia, Washington State, June 21, 1895, may be provisionally referred here, though the hair of the vertex, scutellum, and hind part of mesothorax is black, and the light hair which covers the first two dorsal seoments of the abdomen is strongly inclined to ferruginous. It was collected by Mr. T. Kincaid. 'This Washington form tends towards $A$. sodalis, Cresson, from Nevada, which I feel convinced is only another variety or race of bomboides. A insularis, Smith, from Vancouver Island is known only in the female, but I suspect that it may be a female bomboides of the canadensis type, and belong with the just-mentioned Olympia male. Whether in this case the western form (insularis) can be separated subspecifically from the eastern (canadensis) can only be determined in the light of more ample material. A female from Sioux Co., Nebr., sent by Prof. L. Bruner, resembles the var. neomericana in the colour of the pubescence, but differs in having the hair of the vertex, scutellum, and mesothorax black; herein it resembles insularis, but it differs in having the pubescence of the tibiæ and tarsi black.

Osmia (Chalcosmia) faceta, Cresson, 1878.

Haib. Beulah, May 30, at flowers of Salix, $2 \delta$ (Wilmatte Porter), 1 or (Helen Blake).

A variable species, best known by its steel-blue colour and the structure of the apex of the abdomen.

\section{Osmia (Chalcosmia) densa, Cresson, 1864.}

Hab. Beulah, Aug. 18, 1 (Wilmatte Porter).

New to New Mexico. Known by the hair of the clypeus being black, though that of the adjacent sides of face is white. The anterior margin of the clypeus is quite different from that of female faceta.

Osmia (Ceratosmia) lignaria, Say, var. a.

.- - Smaller, only $9 \frac{1}{2}$ millim. long.

Pale hair on abdomen practically confined to first segment ; 
median impressed line of mesothorax longer, extending as far back as the level of the tegulæ.

Hab. Romeroville, April 29, 1 q at flowers of wild gooseberry (W. Porter); Las Vegas (R. Devine).

It is possible that this is a distinct species, and it may even prove to belong to $O$. montana, Cress., of which only the male has been described.

\section{Osmia (Melanosmia) nigrifrons, Cresson, var. subaustralis, nov.}

9.-Smaller, length 10 millim.

Anterior margin of clypeus with a distinct but broad and shallow emargination, from the middle of which proceeds a very fine raised line traversing the whole length of the clypeus, but only visible in a favourable light; apical tooth of mandibles longer; mesothorax with a smooth sparsely punctured space on the middle of its disk; sides of face tinged with greenish (dark purple-blue in nigrifrons); mesothorax black, with a faint green tinge posteriorly ; wings clearer.

Hab. Beulah, July 26, 1 o (Wilmatte Porter).

Probably a distinct species. Cresson, when describing. nigrifrons, seems to have confused this insect with it, as he says "clypeus truncate or obtusely emarginate."

\section{Osmia (Melanosmia) ribifloris, sp. n.}

\section{o.--Length 11 millim.}

Thickly built (breadth of abdomen 4 millim.), dark shining blue, including the legs, and tegula more or less; pubescence black; wings only faintly tinged with brownish, but the upper half of the marginal cell occupied by a dark brown streak; mandibles very broad, without any patch of rufous hairs, bidentate, the apical tooth quite long, the other small but sharp, nearer to it than to the inner angle; apex of clypeus entire, shining, slightly rounded; punctures of front and mesothorax strong; large, separate; punctures of abdomen distinct but not dense; ventral scopa all black; spurs black; joints 2 to 4 of anterior tarsi inversely cordiform.

Hab. Romeroville, April 29, 1899, 2 o, at flowers of wild gooseberry (Wilmatte Porter); Las Vegas, 1 \& (R. Devine).

Allied to $O$. Bruneri and cobaltina, but larger and much more darkly coloured. The spurs of the hind tibia are small and not hooked at the tip, thus resembling those of cobaltina and differing from those of Bruneri. From several superficially similar species it is distinguished by the blue legs.

\section{Anthidium Porterce, sp. n.}

o. - - Length about 15 millim.

Robust (breadth of abdomen $5 \frac{1}{2}$ millim.) ; black, with white pubescence, pale ochraceous on mesothorax, scutellum, and vertex. Markings pale lemon-yellow; clypeus yellow; wedge-shaped lateral face-marks, ending at the level of the lower part of antennal sockets, mandibles (except their bidentate tips), oblong spot above eyes, mark on each side of mesothorax in front, mark on tegulæ, stripe above tegulæ, four oblong marks on scutellum, stripe on anterior tibia, interrupted stripe on middle tibia, spot at base of hind tibia, basal joint of middle and hind tarsi, and interrupted bands on abdomen pale yellow. The abdominal bands are interrupted in the middle and broadly notched on each side in front, on the first two segments completely divided, on the sixth segment scarcely notched. Apical segment ferruginous, as figured by Cresson for $A$. mormonum, except that the lateral lobes are broader and less curved inwards. Last ventral segment with a single large ferruginous spine, black at tip. Scape with a yellow stripe; labrum black. Wings broadly dusky on outer margin; second recurrent nervure joining second submarginal cell at its tip.

o.-Length about 12 millim.

Marked much like the male, but clypeus black, with a large pale yellow blotch on each side anteriorly, the blotches uniting briefly on the anterior margin; femora and bases of abdominal segments more or less ferruginous; scape entirely black; ventral scopa white. Hardly at all different from the female of cognatum, which, however, is easily distinguished in the male.

Hab. Las Vegas, Aug. 11, 1899, at Howers of Petalostemon candidus, 1 oे (Wilmatte Porter); also in the Mesilla Valley, Aug. 23, at flowers of Cevallia sinuata, ơ (Ckll.), and Mesilla, June 30, $q$ (Ckll.).

This is what I have hitherto recorded as A. maculifrons, Smith, and I believe it is the species so identified by Cresson. Unfortunately maculifrons was described only from the female, and as there are several similar females known in this group, associated with males which have excellent characters at the apex of the abdomen, it may be impossible to certainly identify Smith's species. However, so far as Smith's description goes, it points to $A$. montivagum, Cress., rather than to the present insect, the size being quite too small for $A$. Porterce. It is not known or believed, however, that Smith had any material from the Rocky Mountains, and it is most likely that his insect came from the Southern States. 
Anthidium cognatum, Cresson, must be added to the fauna of New Mexico, having been collected by 'Townsend in the Organ Mountains, the male in Fillmore Cañon, Aug. 29, the female in Soledad Cañon, Aug. 15. I had unfortunately confused this also with maculifions: the apex of the abdomen is black (instead of ferruginous, as it is in Porterce), and is very distinct in its lobes and teeth, as figured by Cresson; the median spine of the last ventral segment is very short, with a long posterior slope, its point directed forwards (cephalad).

Anthidium parosela, Ckll., a small species of the same group, was described only from the female, but I have two males collected at Mesilla, June 17, at flowers of Parosela scoparia, along with the original female. The male has the same face-markings as male Porterce, but the yellow stripe on the scape is rudimentary, the second joint of the flagellum is ferruginons, and the flagellum thence to the tip is ferruginous beneath (in Porterce it is black). The apical lobes of the abdomen are yellow, with hyaline margins, but formed, as also the central and lateral spines, much as in Porterce. The ventral surface of the abdomen is black, and the last ventral segment is not spined.

Anthidium maculosum, Cresson, 1878.

d.-Marked like the female, except that the clypeus and adjacent sides of face are yellow, the upper edge of the lateral yellow, flat, and exactly on a line with the top of the clypeus. Antennæ wholly black. Apex of abdomen black, as also the lateral spines, the whole quite of the type of $A$. cognatum, but the lobes long and very narrow, though blunt at ends.

Hab. Las Vegas, July 6, at flowers of Verbena Macdougali, 1 o (Wilmatte Porter).

The above species are true Anthidium, congeneric with A. manicatum of Europe. The second recurrent nervure is interstitial with the second transverso-cubital, contrary to what is stated by Ashmead in Trans. Amer. Ent. Soc. xxvi. p. 78 .

\section{Dianthidium, n. subg. of Anthidium.}

Type A. curvatum, Smith (interruptum, Say).

Sexes of about the same size; second recurrent nervure passing beyond the tip of the second submarginal cell; apex of male abdomen truncate or somewhat trilobed; hind coxæ usually with a stout spine in male.

This is Cresson's Section 2 (Proc. Ent. Soc. Philad. 1864, p. 374).

Anthidium (Dianthidium) parvum, Cresson, 1878.

This is what has been reported from New Mexico heretofore as $A$. pudicum, but small examples agree sufficiently with Cresson's description of parvum. It differs from pudicum (which is, perhaps, only a race of parvum) by having the pale markings yellow instead of white or cream-colour; male with no supraclypeal mark ( pudicum ${ }^{\lambda}$ has a small triangular mark); a stripe instead of a dot behind the summits of the eyes; apical margin of male abdomen truncate rather than trilobate. The female sometimes has a yellow frontal spot and a supraclypeal spot.

Hab. Las Vegas, June 15, 2 (R. Devine, N. E. Cochran); June 23, at flowers of Cleome serrulata, ot $q(C k l l$.$) ; Aug. 10,$ at flowers of Grindelia squarrosa, 2 (Sarah L. Mize). Santa Fé, Aug. 2, nesting in a hole in an adobe wall, $q$ (Ckll. \& Veer Boyle). Santa Fé, Aug. 2, at flowers of Grindelia squarrosa, of (Ckill.). Also in Colorado (Coll. Amer. Ent. Soc.).

I examined the types of pudicum in Philadelphia.

\section{Anthidium (Dianthidium) perpictum, Ckll., 1898.}

o.-Marked like the female, but the clypeus entirely yellow. Apex of abdomen yellow, with a rounded median lobe, dusky at end, and on each side a hyaline thorn-like spine. Sides of sixth segment not spined. Last ventral segment pellucid reddish testaceous, emarginate at tip, venter before it with a large black concavity.

$H a b$. Las Vegas, July 20, 1 ó ( $W$. Porter); July 31, resting on stems of grass in dull weather, $20(C k l l$.$) ; Aug. 1$, at flowers of Cleome serrulata, 1 o (Ckll.) ; Aug. 5, at flowers of Verbesina encelioides, 1 (Ckll.) ; Aug. 11, at flowers of Petalostenion candidus, 1 o, 1 ( $W$. Porter) ; Aug. 10, at flowers of Grindelia squarrosa, 1 o (Sarah $L$. Mize); Aug. 14, also at Grindelia, 1 \& (W. Porter).

Previously known only by the original type and a female collected by Prof. Townsend at flowers of Erigeron macranthus on Eagle Creek, N. M., about 8000 feet, Aug. 21.

Anthidium (Dianthidium) gilense, Ckll., 1897.

8.-Like the female; clypeus entirely yellow; flagellum 
black; hind coxæ not spined; apex of abdomen yellow, broadly truncate, the sides of the truncation rounded, the middle depressed, so that the apex is obscurely bilobed; no ventral spine.

Hab. Gallinas River at La Cueva, Aug. 6, 3 o (Porter \& Ckll.).

Previously known only by the unique type. A close ally of this species, having a supraclypeal mark, the hind tibix black except at the ends, the abdominal band on the second segment very broadly interrupted, the third to fifth segments with only a large quadrate yellow mark on each side of the middle, and a small spot at the extreme side, the sixth seament with a broad angular or V-like band on each side, the apical segment with four little teeth, is represented by a male collected by Mr. E. M. Ehrhorn in the Mojave Desert, California. The size is small (about 6 millim. long), and the punctures of the scutellum are very dense and irregular instead of being more or less in transverse rows as in.gilense. The colour of the wings, structure, and general type of markings agree so well with gilense that I had no idea it was more than a colourvariety until I saw the quite different apex of the abdomen. For this Mojave Desert species I propose the name Anthidium Ehrhorni.

A. Ehrhorni and A. gilense of the west, with $A$. notatum and $A$. perplesum of the east, form a compact group of closely allied species.

Anthidium occidentale, Cression, 1868.

Hab. Sapello Cañon, Aug. 31, 3 o, 1 o (W. Porter); San Ignacio, Aug. 31 and Sept. 1, 7 o, 3 q (Porter \& Ckll.)

This species will go with Anthidium proper for the present, but with $A$. larrece it really falls in a new group, which may hereafter be separated.

The range of $A$. occidentale is considerably extended by a male from Custer, S. Dakota (L. Bruner, 18).

Nomada modesta, Cresson, 1863. Ckll.).

Hab. Las Vegas, July 12 (A. Garlick), Aug. 1 (Porter \&

Nomada xanthophila, sp. n.

7.-Length 11 millim.

Black and yellow; legs ferruginous and yellow; antennæ ferruginous, black above; apex of abdomen produced, narrowly truncate, entire. Resembles N. superba, Cress., but differs as follows:-Size smaller; head and thorax bare, with practically no pubescence; no supraclypeal mark; eyes entirely surrounded by a narrow band of yellow; scape ferruginous in front (instead of yellow); antenne shorter, unusually short for a male; second joint of flagellum barely, if any, longer than the third; scutellum much less bilobate, it and the postscutellum yellow; sides of metathorax with a dull ferruginous mark; pleura with a very large yellow patch in front; behind this and beneath the wings a red spot, surrounded by black; lower part of pleura ferruginous; wings suffused with brownish along the nervures, which are very dark brown; stigma dark ferruginous; second submarginal cell scarcely narrowed above; legs with more ferruginous; hind coxæ mostly ferruginous within and yellow without; abdomen with the whole of the first segment and the anterior margin of the second ferruginous; abdomen distinctly and very closely punctured; fifth and sixth segments without any apical black band; venter yellow; ferruginous at base, the hind margins of the segments narrowly testaceous. Tegulæ yellow, as in superba.

Hab. Las Vegas, Aug. 11, 1899, at flowers of Solidago canadensis, 1 ơ (Wilmatte Porter).

$$
\text { Halictus aquila, Ckll., } 1898 .
$$

o.-About 9 millim. long.

Very narrow, especially the abdomen; dark olive-green, closely punctured; anterior margin of clypeus broadly, and mandibles except base and apex, lemon-yellow ; legs, ventral surface, and sides of abdomen orange-ferruginous; on the first three abdominal segments the ferruginous sends flamelike projections into the green; the third segment has a dark spot at each extreme side; pubescence of vertex and thoracic dorsum ochraceous, of underparts dull white; antennæ long, reaching to base of abdomen, entirely black; wings strongly infuscated, nervures and stigma piceous. $A$ very beautiful insect.

Hab. Beulah, July 26, at flowers of Ranunculus, Aster, $\& c ., 7$ o $(W$. Porter $)$; the first males were taken at Harvey's Ranch, 9600 feet, Aug. 22, 1899 (Porter \& Ckll.); on Aug. 28 Mliss Porter took males at Beulah. The sexes were taken together, and there is no doubt that they belong. Previously known only by the unique type.

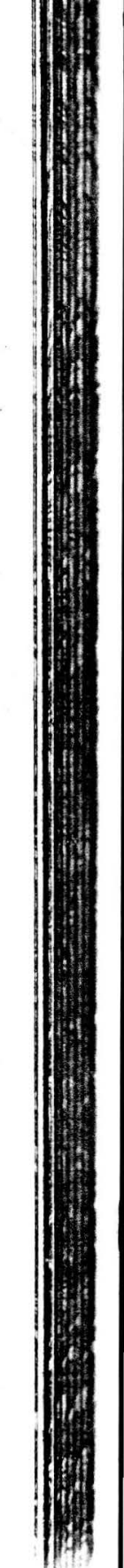


Hemihalictus lustrans (Ckll., 1897).

Hab. Las Vegas, July 18, at flowers of Pyrrhopappus, 4 ㅇ (A. Garlick).

\section{Phileremulus nanus, Ckll., 1895.}

Hab. Las Vegas, Aug. 7, about a patch of Chamcesaracha coronopus, 1 \& $(C k l l$.$) .$

\section{Perdita chamcesaracho, Ckll., 1896.}

Hab. Las Vegas, Aug. 7, at flowers of Chamosaracha coronopus, $1 \delta, 1 q(C k l l$.$) .$

Mesilla Park, New Mexico, U.S.A., Feb. 18, 1900.

LV.-On a new Ostracoderm (Euphanerops longævus) from the Upper Devonian of Scaumenas Bay, Province of Quebec, Canada. By A. Smith WoOdward, LL.D., F.L.S.

[Plate X. figs. $1,1 a, 1 b$.

Dr. TraquaIR's recent memoir on new Silurian fishes from Scotland $*$ suggests the correct interpretation of a problematical fish from the Upper Devonian of Canada which has been for some years in the collection of the British Museum. This specimen was obtained by Mr. Jex from the well-known fish-beds of Scaumenac Bay, in the Province of Quebec, associated with species of Boihriolepis, Diplacanthus, Coccosteus, Scaumenacia, Glyptolepis, Eusthenopteron, and Cheirolepis, which have been described by Whiteaves $\dagger$, 'Traquair $\ddagger$, and myself §. It is preserved in the counterpart halves of a nodule, and the two sides are shown of the natural size in Pl. X. figs. 1, $1 a$.

As indicated by the best side of the fossil (fig. 1), the anterior half of the fish is distorted and its precise contour is destroyed, while the caudal region is well preserved in direct

* Trans. Roy. Soc. Edinb. vol. xxxix. no. 32 (Dec. 1899).

† J. F. Whiteaves, Trans. Roy. Soc. Canada, vol, iv. (1887) sect. iv. p. 101, and ibid. vol. vi. (1888) sect. iv. p. 77.

$\ddagger$ R. H. Traquair, Geol. Mag. [3] vol. vii. (1890) p. 307, and ibid, vol. x. (1893) p. 262.

§ A. S. Woodward, Geol. Mag. [3] vol. ix. (1892) p. 482. 